\title{
Editor's Page
}

In Volume II of MARITIME SEDIMENTS we have attempted to expand the scope of our subject material by including more regional aspects of Atlantic and Appalachian geology. Our first paper by NEALE and KENNEDY is an example of this new thrust; it is also a good account of the geology in a portion of Cape Breton Island, Nova Scotia. In the second paper by PICKERGILI and BRENCHLEY we have a presentation on the scientific conceptalization of fossil communities. It is papers such as these, together with research on recent materials and events, that we hope to maintain our balance in the contents of our magazine. As space permits we intend publishing progress reports, accounts of meetings and other items of current interest.

For our first number of Volume II, we have published parts of a guide book for the Eastern Section of the SEPM, based on a field trip in Nova Scotia held in June, 1975. Because of its length, the total work will be covered in succeeding numbers of Volume II. In the present number, an introduction to the field trip is given, in which route maps, stops and an itinerary are described by HARRIS. This is followed by two of the nine-paper symposium prepared for the trip. The entire work is not only a good record of the field trip, but is a fairly comprehensive documentary on the geology of Nova Scotia and contains excellent reference materials, illustrations and modern.ideas on geological processes. A regional synthesis of this geology is given by SCHENK and a combined account of the Meguma Group has been written by HARRIS and SCHENK. In our next number, more papers on the Paleozoic geology of Nova Scotia will be featured. We hope also to publish work exclusive of the SEPM field trip in order to maintain a reasonable publication schedule for other contributors. Most of the guide book, however, has undergone production and technical editing by I.M. HARRIS with only the final layout and editing by MARITIME SEDIMENTS for the magazine.

Plans for the 25th International Geological Congress to be held in Australia, August 16 to 26,1975 , are well underway with the second circular already distributed. We note with considerable interest that a space has been reserved on the technical program for a session dealing with international aid to developing nations. Many geologists have expressed an interest in providing such services, and many more have given the proposal serious but unexpressed thought. To many it presents a problem that could be defined as moral, ethical, social or economical - perhaps a debt to be paid to one's fellow humans in less fortunate circumstances than their own. It also represents an outlet to fulfill a personal need. All these aspects are on the personal level; there still remain the larger concepts of industrial and governmental aid. Some of this aid may be for political purposes, some for financial and corporate gain, still others for humanitarian reasons. Regardless of the list of aims, the answer to a call for help must rank the highest. Many of the problems to be discussed must surely be centered on equality of wages, training, travel, exchange, contractual obligations, planning, operations, and development. Although the basic geological profession is large on a world scale, many of the subdisciplines have a small scientific base which means that such much-needed expertise must be spread thinly over a wide area, or else be concentrated in small pockets for effective results. Because of this, the demands by the developing nations may not be met. And if they can be met, will the donor nation, corporation or institute accede to the requests of the supplicating nation? Will the developing nation abide by the demands of the donor nation? Will the question of compatible salaries arise; as well as other social aspects? Certainly the meetings last year at Memorial University of Newfoundland (st. John's, Newfoundland) opened many of these avenues of through and concern. The 25th IGC is not expected to culminate in a state of panacea, but it is expected to wrestle further with these problems and take us further down the road to solutions and helpful participation from all the more affluent social, governmental, and industrial sectors of our global society. 